\title{
JOHN GLEDSON
}

Liverpool University, UK

LS: Quais os conceitos que consideraria centrais e mais fecundos na obra critica e historiográfica de Antonio Candido?

Para ser sincero, e pedindo perdão por não responder diretamente à pergunta, o aspecto da obra de Antonio Candido que mais me atrai, e que sempre me atraiu, é justamente a ausência de preconceitos. Nada é excluído a priori, toca-se sem embaraço em assuntos difíceis (o preconceito antiportuguês no ensaio sobre $O$ cortiço, por exemplo); o que também sempre me impressionou é a enorme variedade de assuntos que ele sabe trazer à baila em qualquer situação (o jornalismo satírico da Regência na "Dialética da malandragem", por exemplo). Isso se chama erudição, suponho, mas é mais do que isso - é uma capacidade de transitar entre a literatura e o seu entorno social e histórico que é modelar, e que poucos possuem.

\section{LS: Neste sentido, que obra ou que ensaio the parece exemplar?}

Se for acreditar no meu exemplar de Vários escritos, são os ensaios, lidos e relidos, sobre Machado ("Esquema de Machado de Assis"), e Drummond ("Inquietudes na poesia de Drummond"). Ambos foram escritos para leitores ou ouvintes estrangeiros, mas isso não impede que sejam dos (os?) melhores ensaios sobre esses escritores, que oferecem comparações iluminadoras com romancistas e poetas estrangeiros, e que tocam não só nas obras consagradas, mas também nas "menores" (é o caso dos contos de Machado). O mais extraordinário é que esses ensaios funcionam admiravelmente como apresentações para o leitor novato, mas ainda os releio, com vinte, trinta anos de traquejo com Drummond e Machado.

\section{LS: A perspectiva de Antonio Candido tem vigência crítica no cenário atual?}

Como não iria ter? Uma crítica tão aberta, tão capaz de transitar entre várias disciplinas, que não se limita ao Brasil, sem deixar de valorizar o "nacional", tão 
tolerante - talvez seja isso que queria frisar. Em duas ou três ocasiões, discordei dele, ou não segui o seu ponto de vista, em assuntos bem menores, aliás - a moral da história de "Singular ocorrência", ou a importância 'nacional' de A moreninha são dois exemplos que me ocorrem. Mas me senti inteiramente à vontade para citá-lo, explicar a minha divergência, sem sentir que isso fosse causar espécie - e mais, sempre vale a pena citá-lo por extenso, porque seu ponto de vista é sempre exposto com tal clareza que ajuda a pensar e a expor o nosso argumento. 